\title{
BEE VENOM LOADED CHITOSAN NANOPARTICLES AS TREATMENT FOR AMOEBIASIS IN MICE
}

\author{
By
}

AMANY EL SAYED SABER ${ }^{1 *}$, ABDELWAHAB KHALIL ABDELWAHAB ${ }^{2}$, AZZA MOHAMED EL AMIR ${ }^{3}$, MAMDOUH IBRAHIM NASSAR ${ }^{4}$, And HUSSEIN FOUAD ZOHDI

Department of Chemistry ${ }^{1}$, Faculty of Science, Cairo University, Department of Zoology ${ }^{2}$, Faculty of Science, Beni-Suef University, Beni-Suef, Department of Zoology $^{3}$, Faculty of Science, Cairo University, and Department of Entomology ${ }^{4}$, Faculty of Science, Cairo University, Giza, Egypt

$\left({ }^{*}\right.$ Correspondence: E-mail: amany17elsayed@yahoo.com $)$

\begin{abstract}
Entamoeba histolytica is an invasive parasite and results in intestinal inflammation and amebic liver abscess. Metronidazole is the main used drug for amoebiasis in both adults and children. However, metronidazole has some drawbacks such as having potential mutagenic effects in rats as well as the problem of the emergence of drug- resistance species makes the development of other safer drugs for amoebiasis is critical. In this study we assessed the ability of bee venom (BV) loaded chitosan (CS) nanoparticles to treat amoebiasis and that BV has antiamoebic effect as well as it is proved that orally administered BV loaded CS nanoparticles can be a more effective alternative drug for amoebiasis than subcutaneously injected BV.
\end{abstract}

Keywords: Amoebiasis, Bee venom, Chitosan nanoparticles.

\section{Introduction}

Entamoeba histolytica is an anaerobic protozoan parasitic amoebozoa, member of genus Entamoeba, predominantly infecting man man and other primates causing amoebiasis, and estimated to infect about 50 million people worldwide (Ryan and Ray, 2004). Amoebiasis leads to around 100.000 deaths/year (Houp et al, 2016). The protozoan parasite Entamoeba histolytica results in intestinal ulcer, bowel inflammation and amebic liver abscess (ALA), which is known to be the major extraintestinal manifestations (Sánchez et al, 2016). Infection starts with ingestion of fecally contaminated food or water containing $E$. histolytica cysts. The infective cyst form of the parasite survives passage through stomach and small intestine (Haque et al, 2003). The cysts are resistant form excreted with feces from patients or asymptomatic cyst passers. They lose their wall during passage via the gastrointestinal tract which led to production of trophozoites that colonize the intestinal mucosa (Hughes and Petri, 2000). Under still unclear circumstances, trophozoites are capable of invading the epithelium, the intestinal mucosa, and even deeper in intestine forming bottle flask ulcer (Stanley, 2003).

Cases with amebic colitis gave a severalweek history of watery or bloody diarrhea, weight loss and cramping abdominal pain (Adams and MacLeod, 1977; Aristizabal et al, 1991; Ellyson et al, 1986). Patients with amebic liver abscess typically present with sub-acute onset with fever and pain in the right upper quadrant of the abdomen. Jaundice may be an associated symptom in about $10 \%$ and diarrhea in about $30 \%$ of cases. There may be a few- month history of dysentery before (Maltz and Knauer, 1991; Anesi and Gluckman, 2015).

The treatments for invasive infection differ from that for noninvasive one. Paromomycin may be used for the therapy of noninvasive infections. Nitroimidazoles, especially metronidazole were the mainstay of treatment for invasive amoebiasis (Powell, 1966).

Metronidazole proved the main drug used worldwide to treat invasive amoebiasis in children and adults (Powell et al, 1967; Gardner and Hill, 2001; Farthing, 2006; Jarrad et al, 2016), and nitroimidazole derived compounds like ornidazole, secnidazole and 
tinidazoleare equally effective. Diiodohydroxyquin, diloxanide furoate, paromomycin, chloroquine and emetine have also been used as alternate drugs (Knight, 1980). But, metronidazole proved to acquire mutagenic effect and potential carcinogenicity in rats. Metronidazole, tinidazole and other 5-nitroimidazole agents killed trophozoites by alterations in protoplasmic organelles leading to ineffective in treating cyst passers (Ravdin and Petri, 1995). Lemée et al. (2000) pointed to an increased frequency of cases refractory to metronidazole treatment and emergence of the drug-resistance. So, attention was given for the development of new safer and more effective drugs for amoebiasis.

The applying BV for the treatment of different diseases has been used since ancient times in medicine (Beck, 1935; De Klobusitzky, 1971; Billingham et al, 1973; Hider, 1988). In addition to $88 \%$ water, BV composed of at least 18 components with pharmacological importance including different peptides (apamin, adolapin and melittin), enzymes (hyaluronidase and phospholipase A2), bioactive amines (epinephrine and histamine), and other non-peptide components (free amino acids, lipids and carbohydrates) and minerals ( $\mathrm{Tu}$ et al, 2008; Zhou et al, 2010). BV has been used in medicine for the treatment of a variety of diseases, such as, rheumatism, tumors, arthritis, back pain and skin diseases (Hider, 1988; Somerfield and Brandwein, 1988). As well as, BV has been proofed in vitro the sooner and potent antiprotozoal biogenic agent and it is proved that bee products such as BV can be considered as potent and novel in vitro antiprotozoan agents against Toxoplasma gondii acute tachyzoites stage (Hegazi et al., 2014). Also, some evidence has demonstrated that administration of BV is effective in case of Schistosoma mansoni infection (Mohamed et al, 2014) and can induce different cell death pathways in Trypanosoma cruzi (Adade et al, 2012). Other reported the occurrence of different Programmed cell death
(PCD) phenotypes in Leishmania species (Monte-Neto et al, 2011; Schurigt et al, 2010) and Trypanosoma cruzi (MennaBarreto et al, 2009; Sandes et al, 2010) to the treatment with BV.

New advances in nanotechnology, allow the chance for production of drug nanoparticles which can be utilized in a variety of innovative ways (Jain, 2008). Both natural and synthetic polymers were used in the synthesis of nanoparticles for drug delivery (Tiyaboonchai, 2003). But, among many polymers which were studied for forming nanoparticles, CS has given big attention in pharmaceutical and medical fields (Shahbazi et $a l, 2008$ ), due to its favored properties and advantages such as, biocompatibility, low toxicity, biodegradability, haemostatic, and anticancerogen properties (Hejazi and Amiji, 2003).

CS is a nontoxic, semicrystalline, linear polysaccharide composed of randomly distributed $\mathrm{N}$-acetyl glucosamine and glucosamine units. Indeed, CS is derived from natural chitin which is the second mostly distributed polysaccharide in nature after cellulose (Rinaudo, 2006). CS is widely used for nanoparticles because of its recognized mucoadhesivity and ability of enhancing the penetration of huge molecules across the surface of mucosal membranes (Illum, 1998). CS nanoparticles have been proved to possess great capacity for association of proteins. Moreover, CS nanoparticles are extensively investigated for delivery of polypeptides such as snake venom, diphtheria toxoid and tetanus toxoid (Vila et al, 2004; Rezaei and Alonso, 2006; Ralston and Petri, 2011).

Among different methods developed to prepare the CS nanoparticles, ionic gelation method received great attention because of this process is non-toxic, convenient, controllable and organic solvent free (Agnihotri et al, 2004). Ionic gelation technique is dependent on the ionic interactions between positively charged amino groups of CS molecules and negatively charged groups of polyanion (Shu and Zhu, 2002). Among va- 
riety of polyanions investigated, TPP proved to be widely used due to its quick gelling ability and non-toxic property (Kawashima et al, 1985; Gan et al, 2005).

The aim of this study was to assess the effect of BV in case of amoebiasis and the ability of CS nanoparticles to deliver BV as well as to evaluate the effectiveness of BV loaded CS nanoparticles as a treatment for amoebiasis.

\section{Materials and Methods}

Medium molecular weight CS derived from shrimp shells and BV in the form of lyophilized powder were purchased from Sigma-Aldrich. Bradford protein assay kit which includes bradford reagent and protein standard was purchased from Bio Basic (Canada). Sodium tripolyphosphate (TPP), absolute ethanol and acetic acid were purchased from Merck (Germany). Other reagents used in this work were of analytical grade.

Preparation of CS nanoparticles and BV loaded CS nanoparticles: CS nanoparticles were prepared using ionic gelation method based on cross linking between CS solution and TPP anions. CS was dissolved in $1 \%$ acetic acid $(2 \mathrm{mg} / \mathrm{ml})$, and adjusted to $\mathrm{pH} 5.4$ using $0.1 \mathrm{~N}$ $\mathrm{NaOH}$. TPP dissolved in distilled water as $1.0 \mathrm{mg} / \mathrm{ml}$. To $10 \mathrm{ml}$ of CS solution $5 \mathrm{ml}$ of TPP solution was added drop wise at room temperature using magnetic stirring (1000rpm, 60min) to form an opalescent suspension. Nano-particles

Total amount of venom - Free amount of venom in supernatant

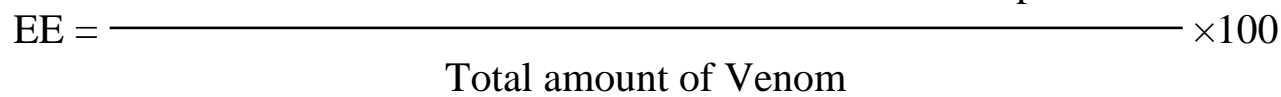

In vitro study: Profile of BV loaded CS nanoparticles was determined by the following method. Suspension of certain amount of the nanoparticles in $3 \mathrm{ml}$ of PBS $0.2 \mathrm{~mol} / \mathrm{lit}, \mathrm{pH}$ 7.4 followed by incubation in a shaking water bath at $37^{\circ} \mathrm{C}, 50 \mathrm{rpm}$ (Mohammadpour Dounighi et al, 2012). Then $100 \mu 1$ of samples were taken from the tube and centrifuged at determined time intervals $(1,2,3$, $5,7,9,17,27,37 \& 42 \mathrm{~h}$ ) after incubation .The samples in the tube were replenished with $100 \mu$ fresh PBS solution at $37^{\circ} \mathrm{C}$. The amount of BV released in the supernatant was measured by the Bradford method. were separated by centrifugation at $12,000 \mathrm{rpm}$, $5 \pm 3^{\circ} \mathrm{C}$ for $30 \mathrm{~min}$, freeze-dried and stored at 4$8^{\circ} \mathrm{C}$. BV loaded CS nanoparticles were formed by the addition of TPP solution containing different concentrations of BV $(20,70,100,550$ \& $700 \mu \mathrm{g} / \mathrm{ml})$ to CS solution. The effect of BV concentrations $(20,70,100,550 \& 700 \mu \mathrm{g} / \mathrm{ml})$ on encapsulation efficiency was also investigated (Nesalin and Smith, 2012; Mohammadpour Dounighi et al, 2012; Zolfagharian et al, 2012; Sharma and Sharma, 2013).

Characterization of prepared nanoparticles: Morphology of prepared nanoparticles was determined using TEM. Particle size, size distribution analysis (PDI, polydispersity index) and zeta potential of nanoparticles were evaluated by Zetasizer (Malvern Instruments), based on dynamic light scattering technique. Also, Fourier transform infrared spectra (FTIR) of CS, CS nanoparticles and BV loaded CS nanoparticles were detected.

Evaluation of encapsulation efficiency: Encapsulation efficiency (EE) was studied as follows. Separation of BV loaded CS nanoparticles from the aqueous suspension was done by centrifugation at $12,000 \mathrm{rpm}$ at $5 \pm 3^{\circ} \mathrm{C}$ for $30 \mathrm{~min}$. The supernatant was collected and protein content (free BV) in supernatant was determined by the Bradford protein assay spectrophotometric method at 595nm (Bradford, 1976; Kruger, 1994). Encapsulation efficiency was calculated according to the following equation as described by Gan and Wang (Gan and Wang, 2007).
Animals: Male C57BL/6 strain, albino mice, 6 to 8 weeks old (25gm), clean from parasitic infection, were obtained from the Schistosome Biological Supply Centre (SBSC), Theodor Bilharz Research Institute (TBRI), Giza. Animals were maintained under standard laboratory care (; and given filtered drinking water and balanced diet.

Parasite: E. histolytica cysts were obtained from diarrheic patients attending parasitology laboratory in outpatient clinic of TBRI.

Drugs: BV was given to mice subcutaneously at a dose of $0.1 \mu \mathrm{g} / \mathrm{g}$. BV loaded CS nanoparicles with encapsulation efficiency 
of $93.3 \%$ were dissolved in saline $(1: 1)$ by mild sonication and each mouse was given orally a volume of nanoprticles solution containing BV with $0.1 \mu \mathrm{g} / \mathrm{g}$ concentration. Similarly, unloaded CS nanoparticles dissolved in saline (1:1) and the same amount as loaded nanoparticles was given orally to mice. All treatments were given for periods of once a week for two weeks and twice for one week.

Studied groups: Each mouse was infected orally by 10,000 of E. histolytica cysts. Animals were divided into eight groups: G1: Control mice. G2: Infected control mice. G3: Infected mice treated with BV twice for one week (double dose). G4: Infected mice treated with BV once a week for two weeks (single dose). G5: Infected mice treated with CS nanoparticles twice for one week (double dose). G6: Infected mice treated CS nanoparticles once a week for two weeks (single dose). G7: Infected mice treated with BV loaded CS nanoparticles twice for one week (double dose) and G8: Infected mice treated BV loaded CS nanoparticles once a week for two weeks (single dose). Animals were sacrificed three weeks post infection

Parasitological study: A week post-infection, stool analysis was done for all to verify infection, and treatments were given. One week later stool analysis was done by direct examination of fresh stool for trophozoites and Merthiolate Iodine Formaldehyde Concentration technique (Blagg et al, 1955). Af- ter sacrificing mice large intestines were excised and colonic contents were examined.

Immunological investigations: Levels of cytokines IL-6, IL-10 \& TNF- $\alpha$ were measured by sandwich ELISA (R\&D systems Inc.) and expressed as pg/mL, (Baqai, 1996). Histopathological study: Large intestine and liver were fixed in $10 \%$ neutral buffered formalin, sections, stained by hematoxylin and eosin (H\&E) and then examined by light microscopy (Tzipori et al, 1981).

Ethical considerations: Studies of the experimental animal were conducted in accordance with international valid guidelines and they were maintained under convenient conditions at the SBSP animal house of TBRI.

Statistical analysis: Data were analysed by Statistical Package for Social Sciences version 23 (copyright by IBM SPSS software, US). Two-ways ANOVA was applied to test the effect of treatment, dosage and their interaction on the studied parameters of experimental mice. Post hoc ANOVA (least significant difference, LSD \& Duncan's test of homo-geneity) tested differences and similarities between groups, respectively. Correlation coefficient and regression analyses were used to fit the relationships between the studied variables. The data were expressed as a mean \pm standard error (SEM).

\section{Results}

The results are shown in tables $(1,2,3 \&$ 4) and figures (1 to 15).

Table 1: Effect of treatment (venom, CS nanoparticles and BV loaded CS nanoparticles), dose (single \& double) and cysts number in intestine and stool of mice.

\begin{tabular}{|l|l|l|l|l|l|l|}
\hline Parameter & Source & SS & df & MS & $\mathrm{F}_{\text {calculated }}$ & P-value \\
\hline Cyst in intestine & Treatment & 396.542 & 2 & 198.271 & 74.937 & $<0.0001$ \\
& Doses & 93.521 & 1 & 93.521 & 35.346 & $<0.0001$ \\
& Treatment * Doses & 29.292 & 2 & 14.646 & 5.535 & $<0.01$ \\
& Error & 111.125 & 42 & 2.646 & & \\
& Treatment & 2322790 & 2 & 1161395 & 3952.684 & $<0.0001$ \\
& Doses & 221544.2 & 1 & 221544.2 & 754.002 & $<0.0001$ \\
& Treatment * Doses & 22497.13 & 2 & 11248.56 & 38.283 & $<0.0001$ \\
& Error & 12340.63 & 42 & 293.824 & & \\
\hline
\end{tabular}

$\mathrm{P}>0.05$ : insignificant effect; $\mathrm{P}<0.05, \mathrm{P}<0.01$ and $\mathrm{P}<0.0001$ : significant effect at $\alpha=0.05,0.01$ and 0.0001 , respectievly. SS: Sum of squares, df: degree of freedom, MS: mean of squares. MS $=S S / d f ; F_{\text {calculated }}=M_{\text {factor }} / M_{\text {error }}$. 
Table 2: Effect of treatment (venom, CS nanoparticles and BV loaded CS nanoparticles), dose (single \& double) and their interactions on levels of IL-10, IL- 6 and TNF- $\alpha$ in the serum of mice.

\begin{tabular}{|l|l|l|l|l|l|l|}
\hline Parameter & Source & SS & Df & MS & F $_{\text {calculated }}$ & P-value \\
\hline IL_10 & Treatment & 95485.88 & 2 & 47742.94 & 20.932 & $<0.0001$ \\
& Doses & 38293.48 & 1 & 38293.48 & 16.789 & $<0.0001$ \\
& Treatment * Doses & 7047.599 & 2 & 3523.799 & 1.545 & $>0.05$ \\
& Error & 95797.28 & 42 & 2280.888 & & \\
IL_6 & Treatment & 81141.43 & 2 & 40570.72 & 15.756 & $<0.0001$ \\
& Doses & 89834.44 & 1 & 89834.44 & 34.887 & $<0.0001$ \\
& Treatment * Doses & 29093.69 & 2 & 14546.84 & 5.649 & $<0.01$ \\
& Error & 108149.2 & 42 & 2574.981 & & \\
& Treatment $\alpha$ & 60048.3 & 2 & 30024.15 & 2.128 & $>0.05$ \\
& Doses & 66256.18 & 1 & 66256.18 & 4.695 & $<0.05$ \\
& Treatment* Doses & 3559.916 & 2 & 1779.958 & 0.126 & $>0.05$ \\
& Error & 592683.4 & 42 & 14111.51 & & \\
\hline
\end{tabular}

$\mathrm{P}>0.05$ : insignificant effect; $\mathrm{P}<0.05, \mathrm{P}<0.01$ and $\mathrm{P}<0.0001$ : significant effect at $\alpha=0.05,0.01$ and 0.0001 , respectievly. SS: Sum of squares, df: degree of freedom, MS: mean of squares. MS $=\mathrm{SS} / \mathrm{df} ; \mathrm{F}_{\text {calculated }}=\mathrm{MS}_{\text {factor }} / \mathrm{MS}_{\text {error }}$ Table 3: Number of cysts in intestine and stool of mice.

\begin{tabular}{|l|l|l|l|}
\hline Treatment & Doses & Cyst in intestine & Cyst in stool \\
\hline Normal & & $0.00 \pm 0.00$ & $0.00 \pm 0.00$ \\
Infected & & $51.13 \pm 2.58^{*}$ & $5581.25 \pm 17.59^{*}$ \\
BV & Double & $8.13 \pm 0.52^{\mathrm{B}^{*}}$ & $724.50 \pm 9.83^{\mathrm{C}^{*}}$ \\
& Single & $13.13 \pm 0.91^{\mathrm{C}^{*}}$ & $803.38 \pm 2.28^{\mathrm{D}^{*}}$ \\
CS nanoparticles & Double & $9.00 \pm 0.71^{\mathrm{B}^{*}}$ & $863.50 \pm 6.64^{\mathrm{E}^{*}}$ \\
& Single & $10.75 \pm 0.31^{\mathrm{BC}^{*}}$ & $1008.50 \pm 5.08^{\mathrm{F}^{*}}$ \\
BV loaded CS nanoparticles & Double & $3.38 \pm 0.26^{\mathrm{A}^{*}}$ & $315.88 \pm 3.82^{\mathrm{A}^{*}}$ \\
& Single & $5.00 \pm 0.46^{\mathrm{A}^{*}}$ & $499.63 \pm 5.82^{\mathrm{B}^{*}}$ \\
\hline
\end{tabular}

$*,:$ Significant difference, at $\alpha=0.05$, in comparison to corresponded normal and infected groups, respectively. In each column, mean values marked with same superscript letter similar (insignificant, $\mathrm{P}>0.05$ ), with different ones significantly differed $(\mathrm{P}<0.05)$.

Table 4: Levels of IL-10, IL-6 and TNF- $\alpha$ in the serum of mice.

\begin{tabular}{|c|c|c|c|c|}
\hline Treatment & Doses & IL-10 & IL-6 & TNF- $\alpha$ \\
\hline Normal & & $124.49 \pm 8.17$ & $136.30 \pm 11.76$ & $150.95 \pm 15.49$ \\
\hline Infected & & $555.95 \pm 40.72^{*}$ & $583.43 \pm 24.21^{*}$ & $620.37 \pm 20.54^{*}$ \\
\hline \multirow[t]{2}{*}{$\mathrm{BV}$} & Double & $205.34 \pm 10.41^{\mathrm{BCD} * \star}$ & $160.91 \pm 16.51^{\mathrm{A}}$ & $225.91 \pm 39.72^{\mathrm{AB}}$ \\
\hline & Single & $259.38 \pm 14.02^{\mathrm{DE}^{*}}$ & $310.92 \pm 22.58^{C^{*}}$ & $301.31 \pm 35.41^{\mathrm{BC}^{*}}$ \\
\hline \multirow[t]{2}{*}{ CS nanoparticles } & Double & $228.02 \pm 17.07^{C D^{*}}$ & $236.04 \pm 10.58^{\mathrm{B}^{*}}$ & $250.50 \pm 27.59^{\mathrm{ABC}}$ \\
\hline & Single & $315.34 \pm 28.48^{\mathrm{E}^{*}}$ & $315.59 \pm 25.43^{\mathrm{C}^{*}}$ & $345.33 \pm 74.86^{\mathrm{C}^{*}}$ \\
\hline \multirow{2}{*}{$\begin{array}{l}\text { BV loaded CS nanoparti- } \\
\text { cles }\end{array}$} & Double & $149.69 \pm 10.30^{\mathrm{AB}}$ & $160.78 \pm 12.03^{\mathrm{A}}$ & $185.52 \pm 19.60^{\mathrm{AB}}$ \\
\hline & Single & $177.80 \pm 14.04^{\mathrm{ABC}}$ & $190.79 \pm 15.67^{\mathrm{AB}^{*}}$ & $238.20 \pm 31.65^{\mathrm{ABC}}$ \\
\hline
\end{tabular}

\section{Discussion}

In the present study, TEM images of the nanoparticles have shown the morphology and surface appearance of nanoparticles. Nanoparticles have smooth surface and spherical shape. The size range of prepared nanoparticles was about $90-140 \mathrm{~nm}$. The average diameter size, measured by Zetasizer, of CS nanoparticles and BV loaded CS na- noparticles was $117 \mathrm{~nm}$ and $161 \mathrm{~nm}$, respectively. The PDI value of CS nanoparticles was 0.313 while PDI value of BV loaded CS nanoparticles was 0.334 , and so indicating a favorable and narrow particle size distribution (Zolfagharian et al, 2012), and relatively homogeneous dispersion (PDI < 0.5).

The results of particle size obtained by Zetasizer showed that BV loaded CS nano- 
particles have larger size than CS nanoparticles, possibly because of the large size and molecular weight of protein, venom adsorption on nanoparticles surface during incubation period and negligible increase of viscosity by venom during loading of nanoparticles (Gan and Wang, 2007).

In this study values of zeta potential for CS nanoparticles and BV loaded CS nanoparticles were 35.2 and $31.2 \mathrm{mV}$, respectively (figure3). These results showed that loading of BV slightly decreased the particle's zeta potential. It was proposed that BV attachment with long CS chain is less spread and does not occur in uniform way. CS molecules are supposed to have a diffuse conformation in solution due to electrostatic repulsion force between the amine groups of CS molecule. Carboxylic groups on the surface of protein molecules created hydrogen bonds with amine groups existing at certain parts of CS chain while maintaining a compact 3-D structure at $\mathrm{pH}$ 5.4. So, inner hydrophobic core of protein molecules remained unchanged (Mao et al, 2001). It is supposed that BV engagement with CS molecules could not greatly suppress the positive charge of CS molecules. There could still be a high proportion of unoccupied free amino groups on the CS chain (Gan and Wang, 2007), and it can be concluded that zeta potential of CS and BV loaded CS nanoparticles can affect their stability in suspension through electrostatic repulsion between particles (Mohammadpour Dounighi et al, 2012).

FTIR was used to assess the formation of BV loaded CS nanoparticles by ionic gelation method and to determine BV-CS interactions (Mohammadpour Dounighi et al, 2012). FTIR spectra of CS matrix, CS nanoparticles and BV loaded CS nanoparticles illustrated (Figs. 4-6). CS was characterized by three peaks (Sharma and Sharma, 2013), the strong and wide peak at $3500-3300 \mathrm{~cm}-1$ corresponds to hydrogen-bonding stretching (O-H) (Yu et al, 1999), the peak of $v(\mathrm{NH} 2)$ at around $1633 \mathrm{~cm}-1$, and the peak of C-O-C the asymmetric stretch was found at about 1150lcm-1 (Zolfagharian et al, 2012). In CS nanoparticles the relative intensity of the peak at $3438 \mathrm{~cm}-1$ increased indicating that the hydrogen bonding was enhanced. Moreover, since protein molecules are consisted of amino acids that interact with each other to produce a well-defined three-dimensional structure (folded protein) which is affected by different solution conditions, the interaction of such protein molecules with cationic CS chain and, consequently, their encapsulation may become difficult depending on the 3-D conformation and conditions of the solution. TPP acts as cross-linker and forms further hydrogen bonds with amine groups on both CS and BV molecules resulting in more compact protein-CS nanoparticles. Additional adsorption of BV molecules on surface of formed nanoparticles might occur in sequence leading to more protein loading on particles (Gan and Wang, 2007).

Also, in CS nanoparticles the peak for N-H bending vibration at $1633 \mathrm{~cm}-1$ shifted to $1562 \mathrm{~cm}-1$ and a new sharp peak appeared at $1642 \mathrm{~cm}-1$. The peak at $894 \mathrm{~cm}-1$ corresponds to the saccharide structure of CS (Silverstein et al, 2005). FTIR spectrum is consistent with the result of CS film modified by phosphate, thus it is supposed that there was interaction between phosphoric and ammonium ion (Knaul et al, 1999). So, the phosphate groups of TPP were linked with amino groups of CS in nanoparticles (Sharma and Sharma, 2013).

Encapsulation of BV within nanoparticles: The results showed that encapsulation efficiency increased by increasing BV concentration. The optimum encapsulation efficiency $(93.3 \%)$ was observed for nanoparticles prepared at CS concentration of $2 \mathrm{mg} / \mathrm{ml}$ and BV concentration of $550 \mu \mathrm{g} / \mathrm{ml}$. The interactions between CS and BV and cross linking of CS with TPP \&BV led to positive correlation between BV concentration and encapsulation efficiency. Studies on the effect of the protein concentration on encapsulation efficiency were inconclusive and sometimes 
contradictory (Zolfagharian et al, 2012). This data agreed with both Mohammadpour Dounighi et al. (2010) and Avadi et al. (2010), but was in contrast with Xu and Du. (2003), who reported opposite results on Bovine serum Albumin (BSA) encapsulation at $\mathrm{pH} 6.0$ and the same trend was also reported by Sabnis and Block (2000) and Somnuk et al. (2011) for $\alpha$-Lactalbumin, cytochrome $\mathrm{C}$ and ribonuclease $\mathrm{A}$.

In vitro release of BV loaded CS nanoparticles was evaluated by using nanoparticles prepared at optimum conditions $(2 \mathrm{mg} / \mathrm{ml} \mathrm{CS}$ $\& 550 \mu \mathrm{g} / \mathrm{ml}$ of BV concentration). The profile of release exhibited a burst releases more than $50 \%$ in the first $5 \mathrm{~h}$. This fast burst effect in the first few hours was the dissociation of protein molecules which were loosely bound to surface of CS nanoparticles (Amidi et al, 2006). The nanoparticles with huge specific surface adsorbed the venom causing in fast release of venom in the early few hours and subsequent release the slow degradation of nanoparticles led to release of entrapped venom with a constant rate (Zolfagharian et al, 2012).

In the present study, the different factors (i.e. treatments, doses and interaction between treatments and doses) were significantly affected $E$. histolytica cysts number in intestine and stool of experimental mice as well as the level of serum cytokines (IL-6, IL10 \& TNF- $\alpha$ ).

In this study, number of cysts in intestine and stool was significant higher than number of cysts in treated mice as well as in the control mice. The mice treatment with $\mathrm{BV}, \mathrm{CS}$ nanoparticles and/or BV loaded CS nanoparticles caused non-significant decrease in number of cysts in intestine and stool compared to infected group with the lowest count of cysts in intestine and stool recorded in the group treated with BV loaded CS nanoparticles given at double dose.

In the present work, the levels of cytokines (IL-6, IL-10 and TNF- $\alpha$ ) in the infected mice group are much higher than levels of cytokines in the treated mice groups. But, cytokines levels in treated groups were slightly higher than the normal mice. The highest reduction in the levels of cytokines was among the treated mice groups observed in the mice group treated with BV loaded CS nanoparticles given at double dose.

In the present study, there was a strong positive correlation between the number of cysts in stool and their number in intestine in some mice groups (e.g. group 3,4) however, there is a week correlation between these parameters in others (e.g. group 2, 5). There were positive correlations between IL- 6 and IL-10 and strong correlations (positive/ negative) between TNF- $\alpha$ with both IL-6 \& IL10 , which correlated between different parameters among mice groups related to different immune status and heath conditions.

In the present study, injecting BV subcutaneously led to significant reduction in $E$. histolytica in intestine and stool due to the fact that BV is potent anti-protozoal biogenic agent. Also, it is important to mention that there is a significant difference in the reduction of counts of cysts and levels of cytokines between treatment with $\mathrm{BV}$ and treatment with BV loaded CS nanoparticles as the later led to higher reduction in these parameters as BV alone. So it can be concluded that CS nanoparticles have efficient capacity to deliver $\mathrm{BV}$ and to facilitate the elimination of amoebiasis. Moreover, unloaded CS nanoparticles resulted in good results on the count of cysts and the levels of cytokines with zero mortality in mice thus it can be deduced that CS nanoparticles have no toxicity on experimental mice.

Histophathological results indicated that G2 (infected control mice) showed extensive intestinal inflammation, degeneration of the intestinal mucosa and presence of marked liver abscess, G3 (infected mice treated with BV twice for one week) showed moderate intestinal inflammation, regeneration and healing of intestinal villi and normal liver, G4 (Infected mice treated with BV once a week for two weeks) showed intestinal inflammation more than G3, degeneration and 
healing in intestinal villi and liver abscess, G5 (infected mice treated with CS nanoparticles twice for one week) showed marked intestinal inflammation, regeneration of intestinal villi and normal liver, group6 (infected mice treated CS nanoparticles once a week for two weeks) showed marked intestinal inflammation, partial degeneration and healing of intestinal villi and liver necrosis, G7 (infected mice treated with BV loaded CS nanoparticles twice for a week) showed complete healing in intestinal villi and normal liver and G8 (infected mice treated BV loaded CS nanoparticles once a week for two weeks) showed regeneration and healing in intestinal villi and normal liver. Histopathological examination revealed complete healing in G8 treated with BV loaded CS nanoparticles twice for one week. This indicates that the best result for the elimination of amoebiasis in the mice treated with BV loaded CS nanoparticles given twice for one week and when BV, CS nanoparticles and BV loaded CS nanoparticles were given at double dose (twice for one week) they resulted in better effects than when single dose (once a week for two weeks).

\section{Conclusion}

In this study, BV loaded CS nanoparticles were prepared successfully based on ionic gelation method. FTIR spectra indicate that there was cross linking between CS molecules and TPP anions, and favored size distribution and good dispersion. Also, CS nanoparticles showed acceptable encapsulation efficiency of $93.3 \%$ for BV. Thus, CS nanoparticles can be considered as a promising delivery system of BV in an effective way. As well as results of the effect of BV, CS nanoparticles and BV loaded CS nanoparticles on amoebiasis in mice indicated that $\mathrm{BV}$ has anti-amoebic effect and BV loaded CS nanoparticles proved more successful in treating amoebiasis than $\mathrm{BV}$ alone.

\section{References}

Adade, C, Chagas, GSF, Souto-Padr Ón, T, 2012: Apis mellifera venom induces different cell death pathways in Trypanosoma cruzi. Parasitol. 139:1444-61.

Adams, EB, MacLeod, IN, 1977: Invasive amebiasis. I. Amebic Dysentery and Complications. Medicine (Baltimore), USA.

Agnihotri, SA, Mallikarjuna, NN, Aminabhavi, TM, 2004: Recent advances on chitosanbased micro- and nanoparticles in drug delivery. J. Control Release 100:5-28.

Amidi, M, Romeijn, SG, Borchard, G, Junginger, HE, Hennink, WE, et al, 2006: Preparation and characterization of protein-loaded $\mathrm{N}$ trimethyl chitosan nanoparticles as nasal delivery system. J. Control Release 111:107-16.

Anesi, JA, Gluckman, S, 2015: Amebic liver abscess, review. Clinical liver disease. A Multimedia Rev. J. 6, 2:3-41.

Aristizabal, H, Acevedo, J, Botero, M, 1991: Fulminant amebic colitis. World J. Surg. 15: 216-21.

Avadi, MR, Mir Mohammad Sadeghi, A, Mohammadpour Dounighi, N, Abedin, S, Atyabi, F, et al, 2010: Preparation and chatacterization of Insulin nanooarticles using chitosan and Arabic gum with ionic gelation method. Nanomed. Nanotech. Biol. Med. 6:58-63.

Baqai, R, 1996: Role of cytokines in parasitic disease. J. Pak. Med. Assoc. 46:48-49.

Beck, BF, 1935: Bee Venom Therapy. New York: Appleton-Century by Schmidt and Buchmann. In : The Hive and the Honey Bee, Edited by Joe, M., Graham, Dadant and Sons, Hamilton, Illinois.

Billingham, ME, Morley, J, Hanson, JM, Shipolini, RA, Vernon, CA, 1973: An anti-inflammatory peptide from bee venom. Nature. 245: 163-4.

Blagg, W, Mansour, NS, Khalof, Gl, 1955: A new concentration technique for the demonstration of protozoa and helminthic egg in faeces.

Am. J. Trop. Med. Hyg. 14:23.

Bradford, M, 1976: A rapid and sensitive method for the quantitation of microgram quantities of protein utilizing the principle of protein-dye binding. Anal. Biochem. 72:248-54.

De Klobusitzky, D, 1971: Animal venoms in therapy. In: Venomous Animals and Their Venoms, V. III, Venomous Invertebrates, Buckley E and Deulofeu V (Eds). Academic Press, New York.

Ellyson, JH, Bezmalinovic, Z, Parks, SN, Lewis, FR, 1986: Necrotizing amebic colitis: A 
frequently fatal complication. Am. J. Surg. 152: 6-21.

Farthing, MJ, 2006: Treatment options for the eradication of intestinal protozoa. Nat. Clin. Pract. Gastroenterol. Hepatol. 3, 8:436-45.

Gan, Q, Wang, T, 2007: Chitosan nanoparticle as protein delivery carrier-Systematic examination of fabrication conditions for efficient loading and release. Colloids Surf. B. 59:24-34.

Gan, Q, Wang, T, McCarron, P, 2005: Modulation of surface charge, particle size and morpholo-gical properties of chitosan-TPP nanoparticles intended for gene delivery. Colloids Surf. B. 44:65-73.

Gardner, TB, Hill, DR, 2001: Treatment of giardiasis. Clin. Microbial Rev. 14, 1:114-28.

Haque, R, Huston, CD, Hughes, M, Houpt, E, Petri, WA, 2003: Amebiasis. N. Engl. J. Med. 348:1565-73.

Hegazi, AG, Abdou, AM, Abd Allah, F, 2014: Evaluation of the antibacterial activity of bee venom from different sources. World Appl. Sci. J. 30:266-70.

Hejazi, R, Amiji, M, 2003: Chitosan-based gastrointestinal delivery systems. J. Control Release 89:11-6.

Hider, RC, 1988: Honeybee venom: A rich source of pharmacologically active peptides. Endeavour 12, 2:60-65.

Hughes, M, Petri, W, 2000: Amebic liver abscess. Infect. Dis. Clin. North Am. 14:565-82.

Illum, L, 1998: Chitosan and its use as a pharmaceutical excipient. Pharm. Res. 15:1326-31.

Jain, KK, 2008: Nanopharmaceuticals. In: The Handbook of Nanomedicine. Basel: Humana Press.

Jarrad, AM, Debnath, A, Miyamoto, Y, et al, 2016: Nitroimidazole carboxamides as antiparasitic agents targeting Giardia lamblia, Entamoeba histolytica and Trichomonas vaginalis. Eur. J. Med. Chem. 120:353-62.

Kawashima, Y, Handa, T, Kasai, A, Takenaka, H, Lin, SY, et al, 1985: Novel method for the preparation of controlled-release theophylline granules coated with a polyelectrolyte complex of sodium polyphosphate-chitosan. J. Pharm. Sci. 74:264-68.

Knaul, JZ, Hudson, SM, Creber, KAM, 1999: Improved mechanical properties of chitosan fibers. J. Appl. Polym. Sci. 72:1721-31.

Knight, R, 1980: The chemotherapy of amoebiasis. J. Antimicrob. Chemother. 6:577-93
Kruger, N, 1994: The Bradford method for protein quantitation. Methods Mol. Biol. 32:9-15.

Lemée, V, Zaharia, I, Nevez, G, Rabodonirina, M, Brasseur, P, et al, 2000: Metronidazole and albendazole susceptibility of 11 clinical isolates of Giardia duodenalis from France. J. Antimicrob. Chemother. 46, 5:819-21.

Maltz, G, Knauer, CM, 1991: Amebic liver abscess: A 15-year experience. Am. J. Gastroenterol. 86:704-10.

Mao, HQ, Roy, K, Troung-Le, VL, 2001: Chitosan DNA nanoparticles as gene delivery carriers: synthesis, characterization and transfection efficiency. J. Control Release. 70: 399-421.

Menna-Barreto, RFS, Salomão, K, Dantas, AP, Santa- Rita, RM, Soares, MJ, et al, 2009: Different cell death pathways induced by drugs in Trypanosoma cruzi: An ultrastructural study. Micron. 40:157-68.

Mohamed, AH, Hassab El-Nabi, SE, Bayomi, AE, Abdelaal, AA, 2014: Effect of bee venom or proplis on molecular and parasitological aspects of Schistosoma mansoni infected mice. J. Parasit. Dis. 12:1-11.

Mohammadpour Dounighi, N, Behfar, A, Ezabadi, A, Zolfagharian, H, Heydari, M, 2010: Preparation of Chitosan nanoparticles containing Naja-naja oxiana snake venom. Nanomed. 6: 137-43.

Mohammadpour Dounighi, N, Eskandari, R, Avadi, MR, Zolfagharian, H, Mir Mohammad Sadeghi, A, et al, 2012: Preparation and in vitro characterization of chitosan nanoparticles containing Mesobuthus eupeus scorpion venom as an antigen delivery system. J. Venom. Anim. Toxins Incl. Trop. Dis. 18:44-52.

Monte Neto, RL, Sousa, LM, Dias, CS, Barbosa Filho, JM, Oliveira, MR, et al, 2011: Morphological and physiological changes in Leishmania promastigotes induced by yangambin, a lignan obtained from Ocotea duckei. Exp. Parasitol. 127:215-21.

Nesalin, JA, Smith, AA, 2012: Preparation and evaluation of chitosan nanoparticles containing zidovudine. Asian J. Pharm. Sci. 7:80-84.

Powell, SJ, MacLeod, I, Wilmot, AL, Elsdondew, E, 1966: Metronidazole in amoebic dysentery and amoebic liver abscess. Lancet 2:132931.

Powell, SJ, Wilmot, AJ, Elsdon-Dew, R, 1967: Further trials of metronidazole in amoebic dysentery and amoebic liver abscess. Ann. Trop. Med. Parasitol. 61, 4: 511-4. 
Ralston, K, Petri W, 2011: Tissue destruction and invasion by Entamoeba histoltica. Trends Parasitol. 27:253-62.

Ravdin, JI, Petri, WA, 1995: Entamoeba histolytica (amoebiasis). In: Mandell, G.L., Bennett, J.E., Dolin, R., editors. Mandell, Douglas and Bennett's principles and practice of infectious disease. New York: Churchill Livingstone.

Rezaei Mokarram, A, Alonso, MJ, 2006: Preparation and evaluation of chitosan nanoparticles containing Diphtheria toxoid as new carriers for nasal vaccine delivery mice. Arch. Razi. Inst. 61:13-25.

Rinaudo, M, 2006: Chitin and chitosan: Properties and applications. Prog. Polym. Sci. 31: 603-32.

Ryan, KJ, Ray, CG, 2004: Sherris Medical Microbiology. $4^{\text {th }}$ ed. Mc-Graw Hill.

Sabnis, SS, Block, LH, 2000: Chitosan as an enabling excipient for drug delivery systems 1 . molecular modifications. Int. J. Biol. Macromol. 27:181-6.

Sánchez, V, Serrano-Luna, J, Ramírez-Moreno, E, Tsutsumi, V, Shibayama, M, 2016: Entamoeba histolytica: Overexpression of the gal/galnac lectin, ehcp2 and ehcp5 genes in an in vivo model of amebiasis. Parastol. Int. 65:665-7.

Sandes, JM, Borges, AR, Junior, CG, Silva, F P, Carvalho, GA, et al, 2010: 3- Hydroxy-2-methylene-3-(4-nitrophenylpropanenitrile): A new highly active compound against epimastigote and trypomastigote form of Trypanosoma cruzi. Bioorg. Chem. 38:190-5.

Schurigt, U, Schad, C, Glowa, C, Baum, U, Thomale, K, et al, 2010: Aziridine-2,3-dicarboxylate-based cysteine cathepsin inhibitors induce cell death in Leishmania major associated with accumulation of debris in autophagyrelated lysosome-like vacuoles. Antimicrob. Agents Chemother. 54:5028-41.

Shahbazi, MA, Hamidi, M, Peymani, P, 2008: Interaction of chitosan, a natural polymer used in Nanodrug/gene delivery, with non-steroidal anti-inflammatory drugs (NSAIDs). Internet. J. Nanotech. 2.

Sharma, S, Sharma, U, 2013: Synthesis, characterisation and determination of encapsulation efficiency of chitosan nanoparticles for terbinafine. Indo. Am. J. Pharm. Res. 3:1564-67.

Shu, XZ, Zhu, KJ, 2002: The influence of multivalent phosphate structure on the properties of ionically cross-linked chitosan films for control- led drug release. Eur. J. Pharm. Biopharm. 54: 235-43

Silverstein, RM, Webster, FX, Kiemle, D, 2005: Infrared espectrometery, Spectromic Identification of Organic Compounds. $7^{\text {th }}$ ed. John Wiley and Sons, New York.

Somerfield, S.D., Brandwein, S, 1988 : Bee venom and adjuvant arthritis. J. Rheumatol. 15, 12:878-82.

Somnuk, J, Anupap, T, Virote, B, 2011: Preparation of chitosan nanoparticles for encapsulation and release of protein. Korean J. Chem. Eng. 28;1247-51.

Stanley, Jr, 2003: Amoebiasis. Lancet 361: 1025-34.

Tiyaboonchai, W, 2003: Chitosan nanoparticles: A promising system for drug delivery. Naresuan U. J. 11:51-66.

Tu, WC, Wu, CC, Hsieh, HL, Chen, CY, Hsu, SL, 2008: Honeybee venom induces calcium dependent but caspase-independent apoptotic cell death in human melanoma A 2058 cells. Toxicon. 52:318-29.

Tzipori, S, McCartney, E, Lawson, GHK, Rowland, AC, Campbell, I, 1981: Experimental infection of piglets with Cryptosporidium. Res. Vet. Sci. 31:358-68.

Vila, A, Sánchez, A, Janes, K, Behrens, L, Kissel, T, et al, 2004: Low molecular weight chitosan nanoparticles as new carriers for nasal vaccine delivery in mice. Eur. J. Pharm. Biopharm. 57:123-31.

Xu, Y, Du, Y, 2003: Effect of molecular structure of chitosan on protein delivery properties of chitosan nanoparticles. Int. J. Pharm. 250:21526.

Yu, JH, Du, YM, Zheng, H, 1999: Blend films of chitosan-gelation. Wuhan Univ. J. Nat. Sci. 45:440-4.

Zhou, J, Zhao, J, Zhang, S, Shen, J, Qi, Y, et al, 2010: Quantification of melittin and apamin in bee venom lyophilized powder from Apis mellifera by liquid chromatography-diode array detector-tandemmass spectrometry. Anal. Biochem. 404:171-8.

Zolfagharian, H, Damavandi, M. Mohammadpour Dounighi, N, Moradi, S, 2012: Preparing and characterizing chitosan nanoparticles containing Hemiscorpius lepturus Scorpion Venom as an Antigen Delivery System. Arch. Razi. Inst. 67:145-53. 


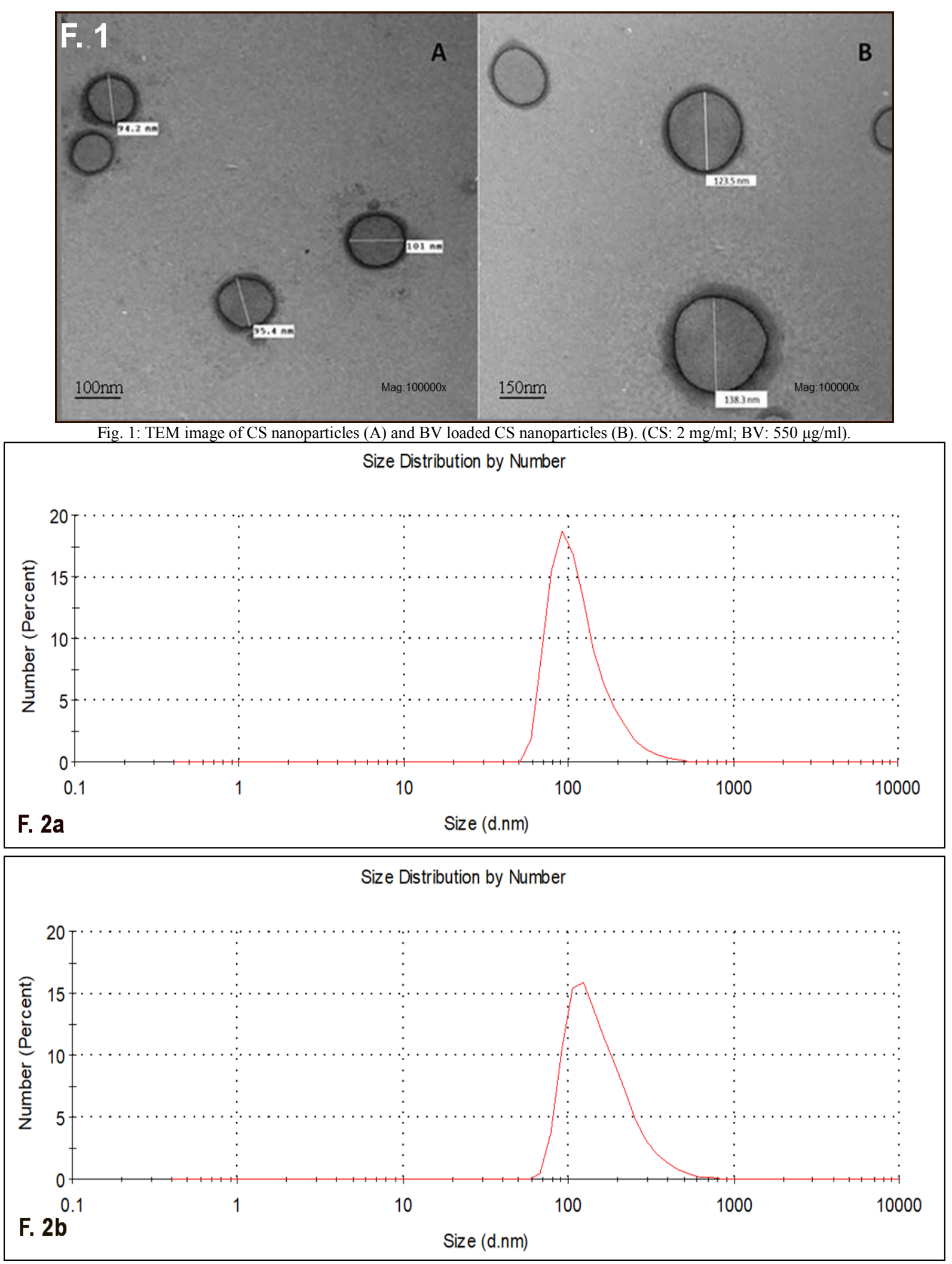

Fig. 2: Size analysis of CS nanoparticles (A) and BV loaded CS nanoparticles (B). 

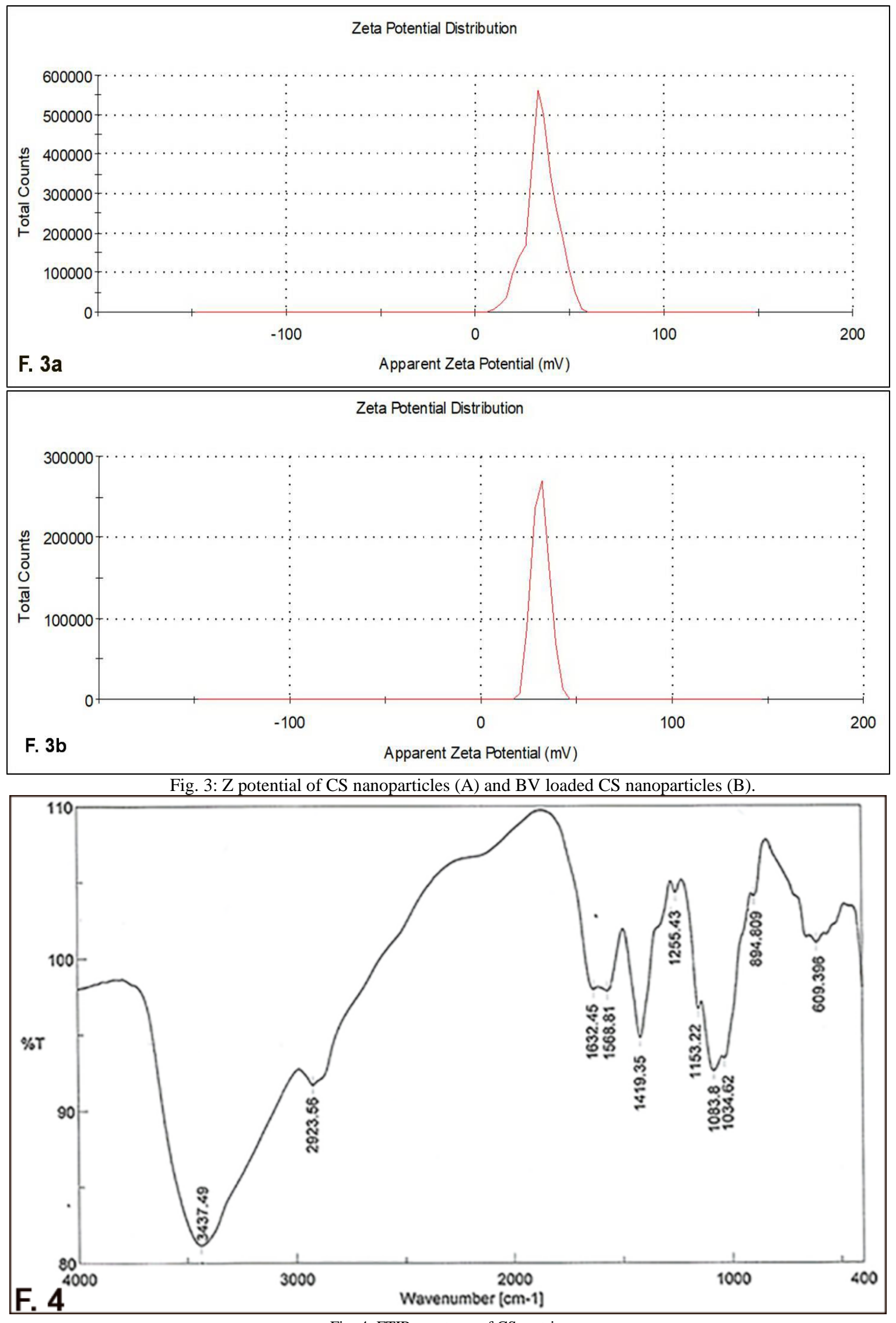

Fig. 4: FTIR spectrum of CS matrix. 

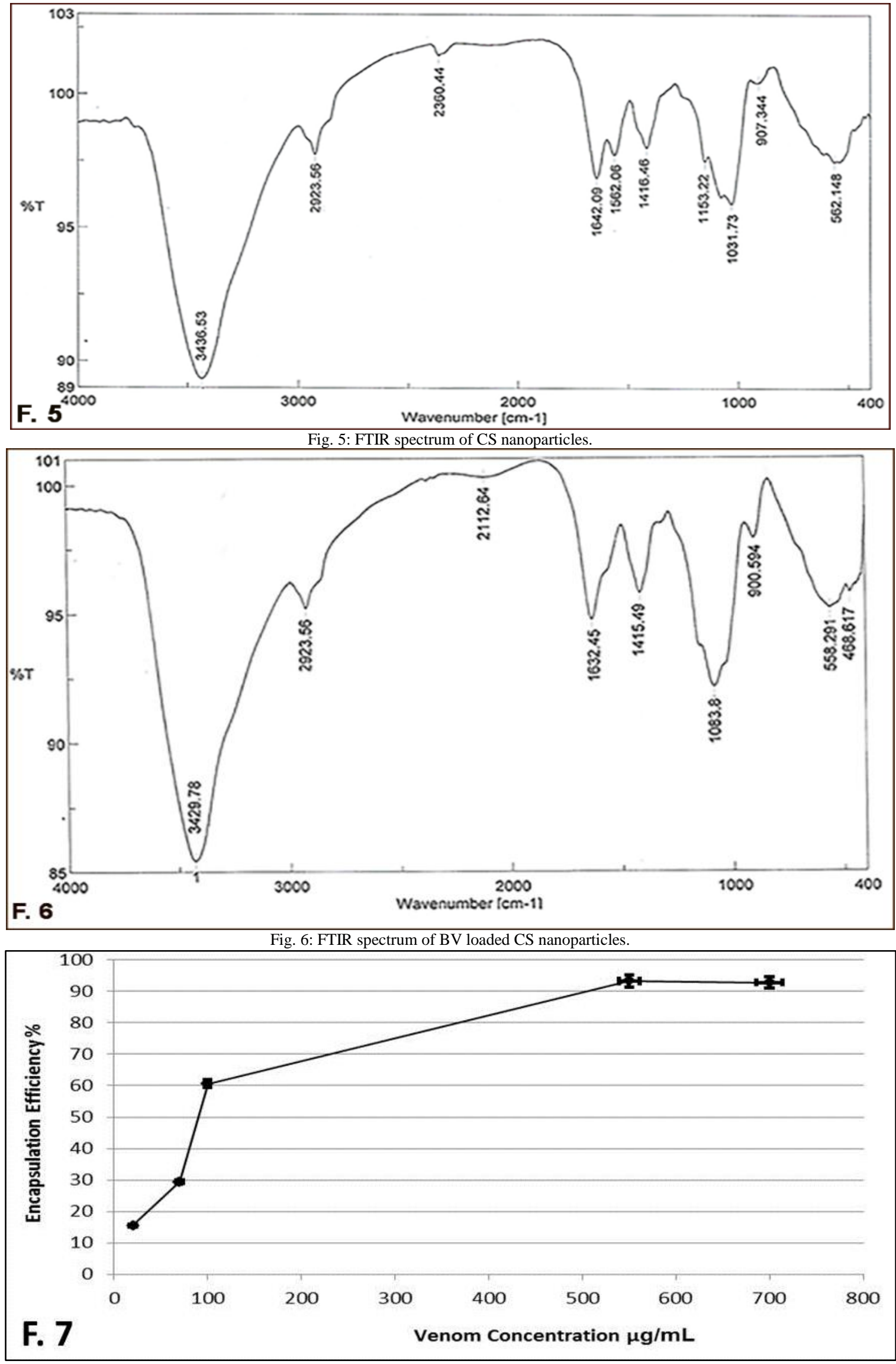

Fig. 7: Influence of BV initial concentration on encapsulation efficiency (CS: $2 \mathrm{mg} / \mathrm{ml}$; TPP: $1 \mathrm{mg} / \mathrm{ml})$. 


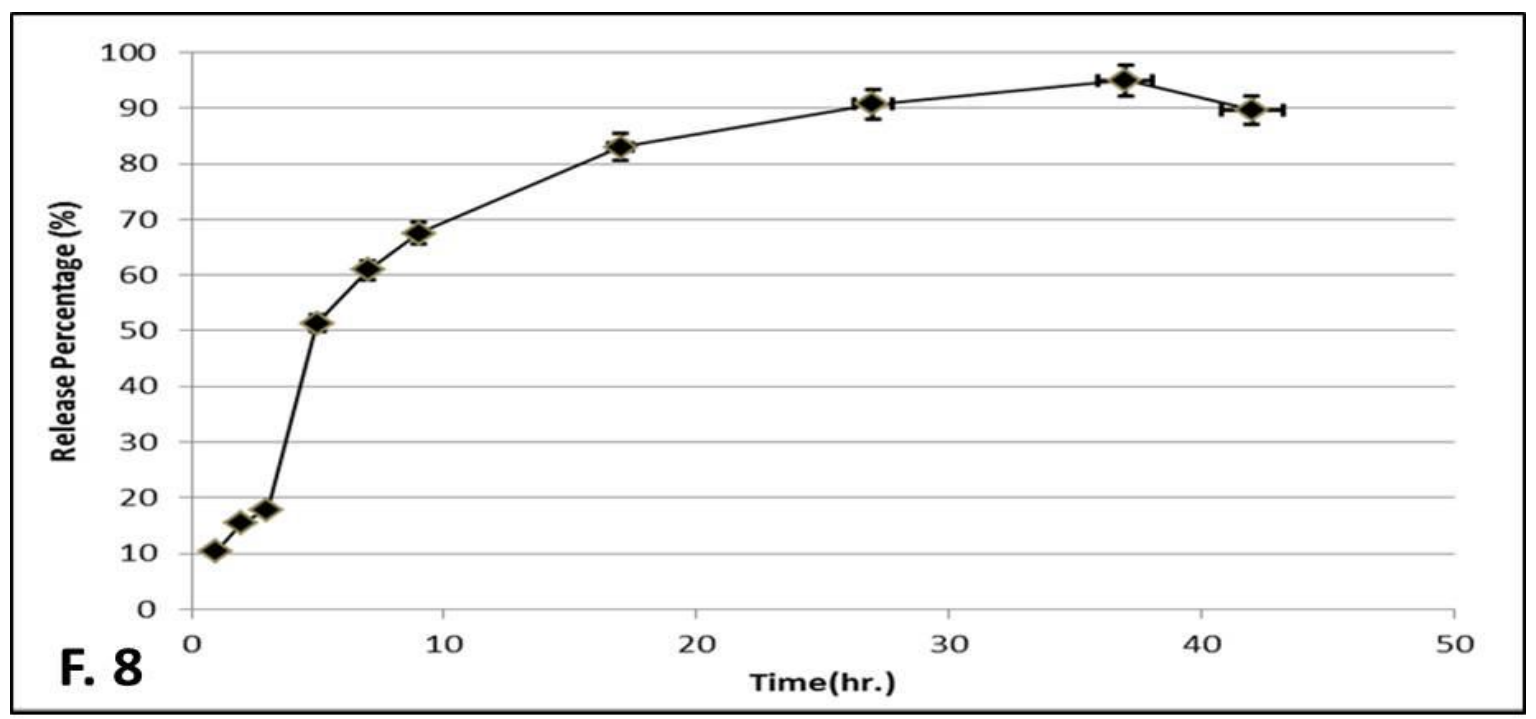

Fig. 8: In vitro release behavior of BV loaded CS nanoparticles (CS: $2 \mathrm{mg} / \mathrm{ml}, \mathrm{BV}: 550 \mu \mathrm{g} / \mathrm{ml}$ ).
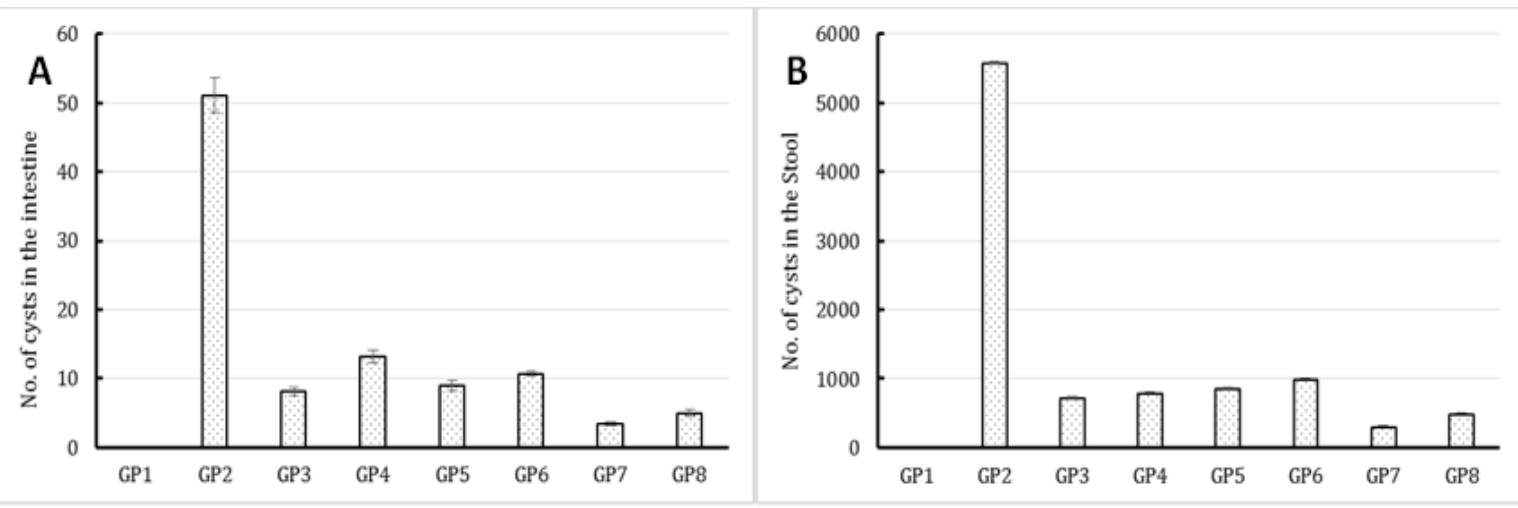

Figure9: graphical illustration for the difference in number of cysts in intestine (A) and stool (B) among mice groups.
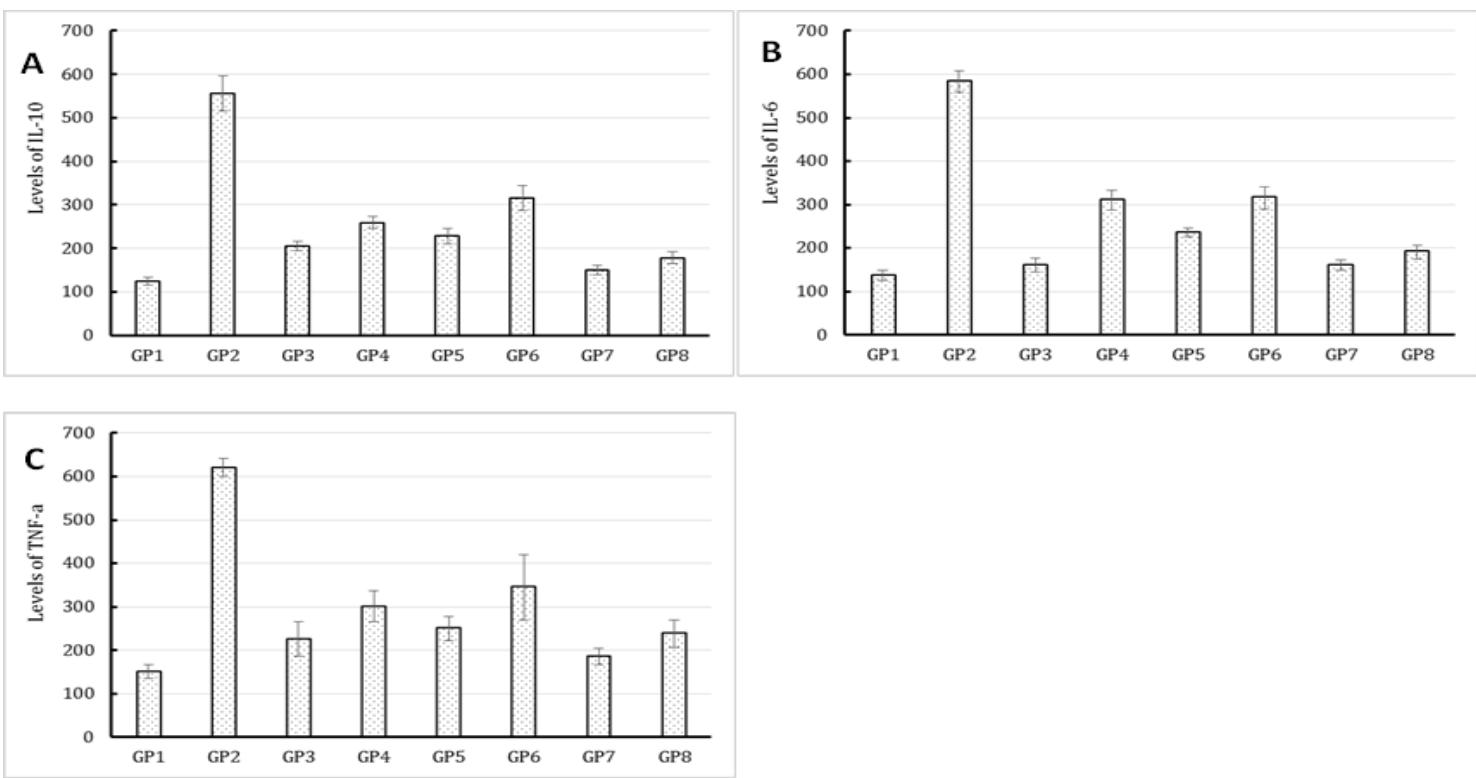

Fig. 10: Graphical illustration for differences in levels of IL-10 (A), IL-6 (B) and TNF- $\alpha$ (C) among mice groups. 


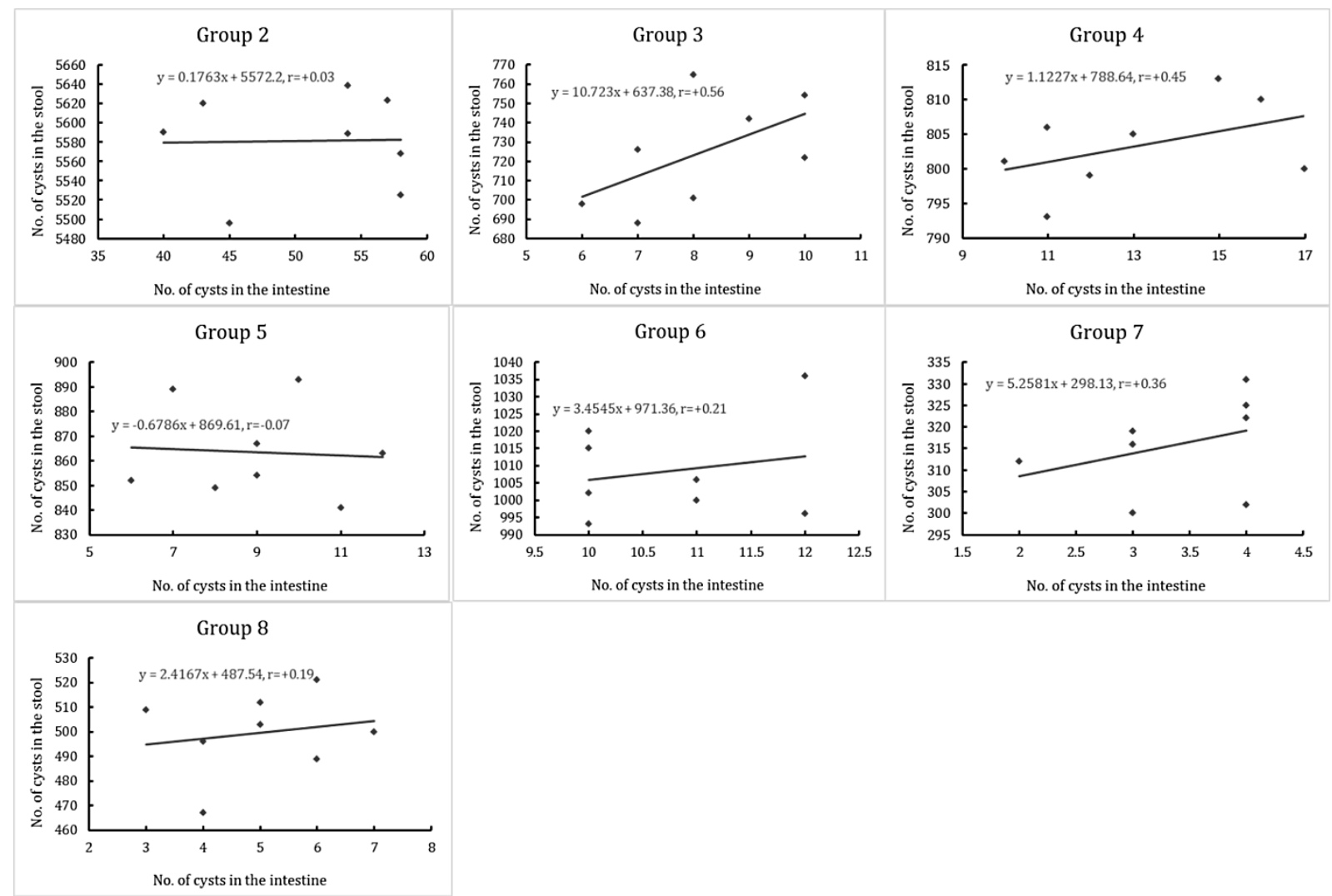

Fig. 11: Correlation between number of cysts in stool and number of cysts in intestine among mice groups.

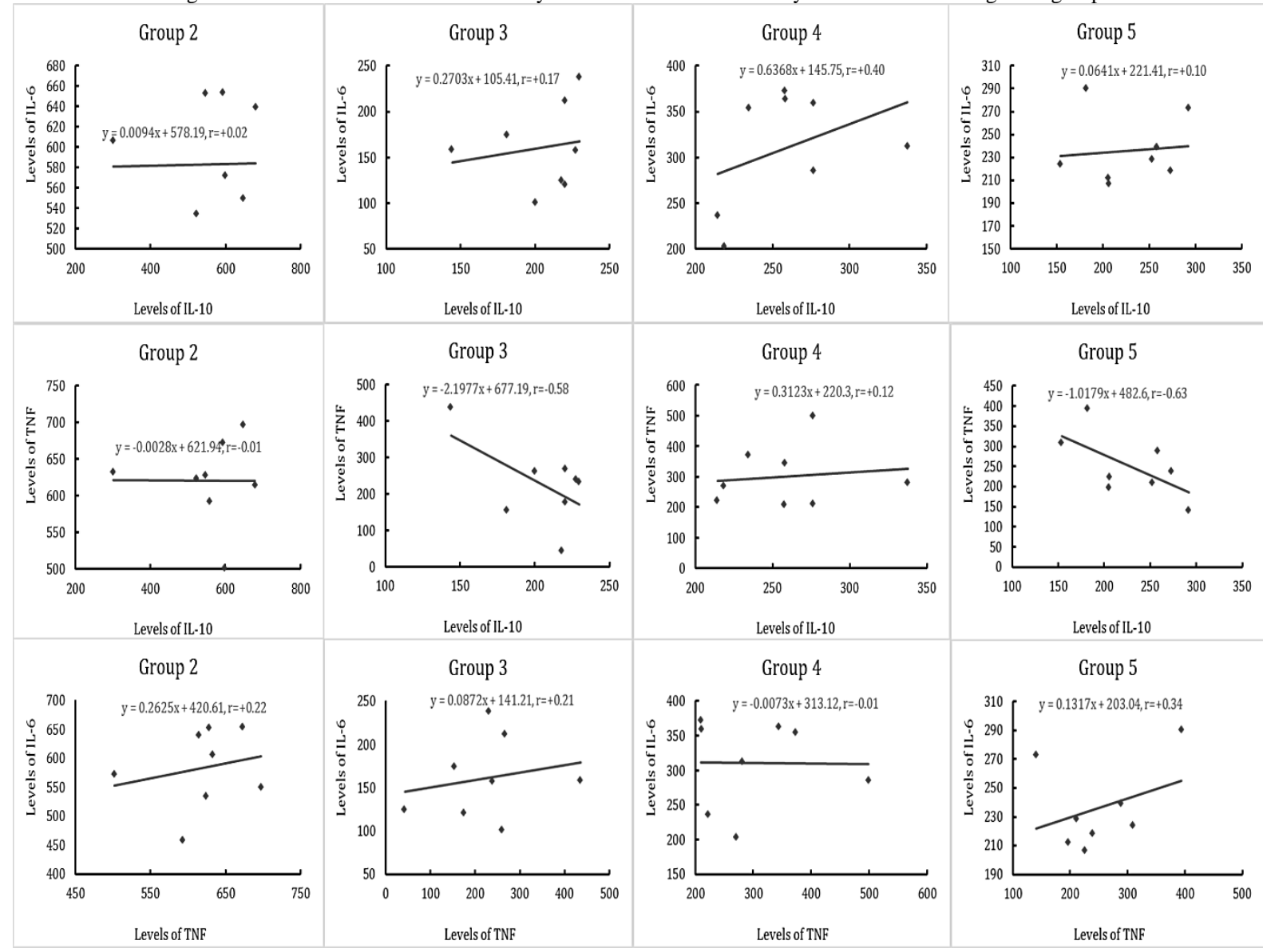

Fig. 12: Graphical illustration for correlation between levels of IL-6 and IL-10, IL-6 and TNF- $\alpha$, IL-10 and TNF- $\alpha$ in mice groups(2-5). 

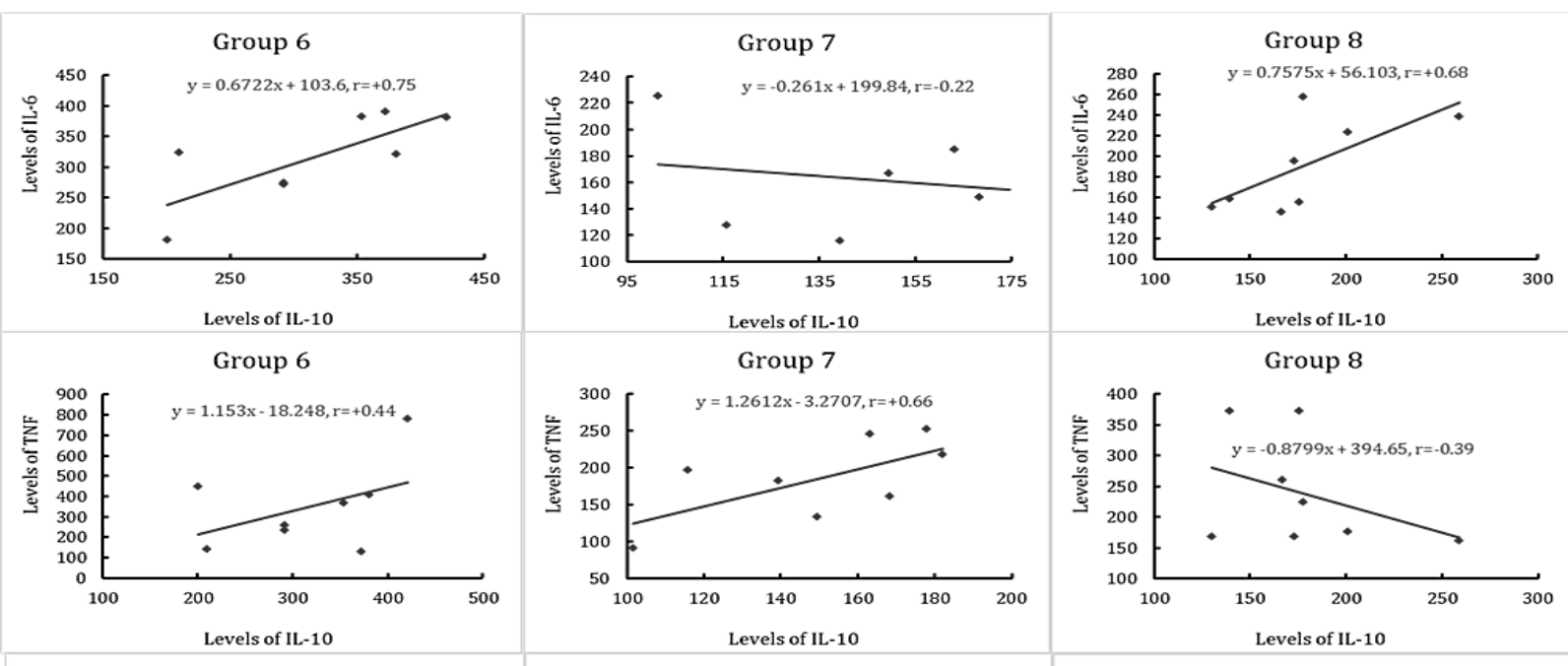

Group 6
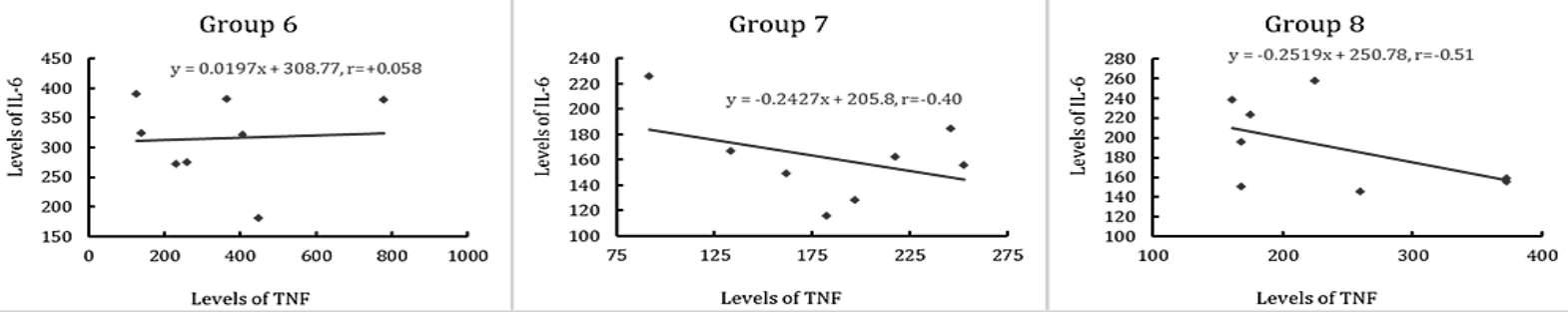

Fig. 13: Graphical illustration for correlation between levels of IL-6 and IL-10, IL-6 and TNF- $\alpha$, IL-10 and TNF- $\alpha$ in mice groups (6-8).

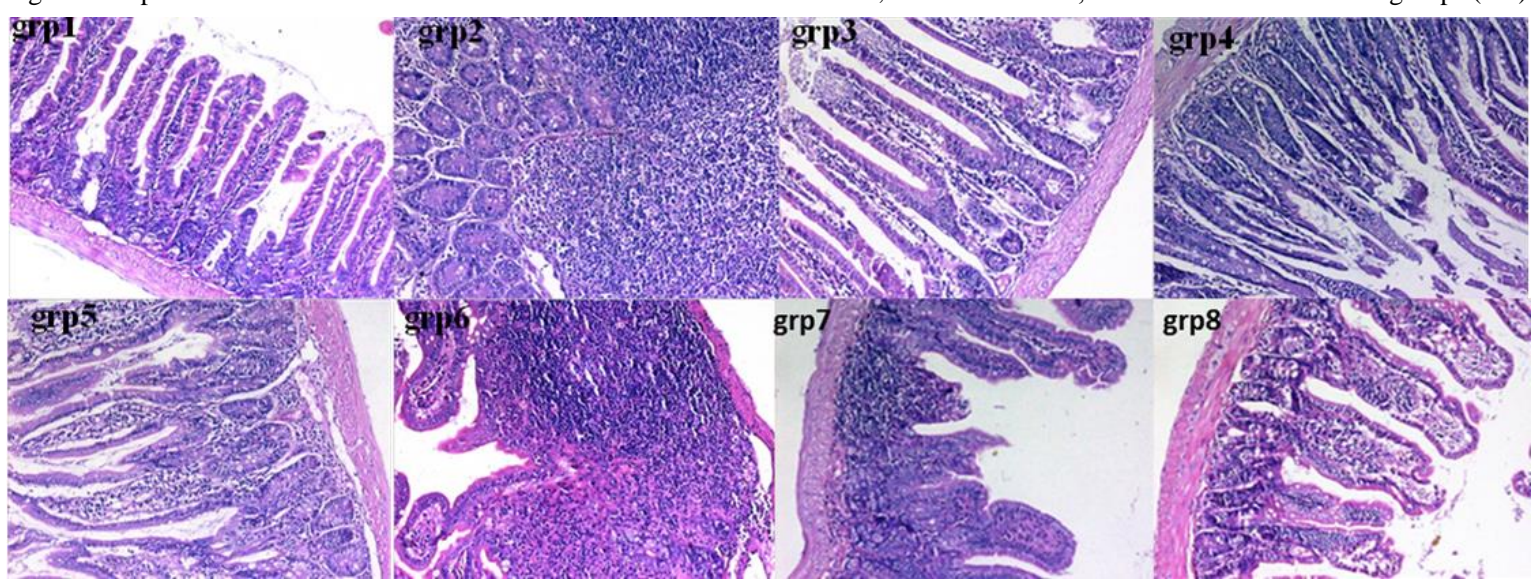

Fig. 14: Histopathological study for intestine of eight mice groups (X40).

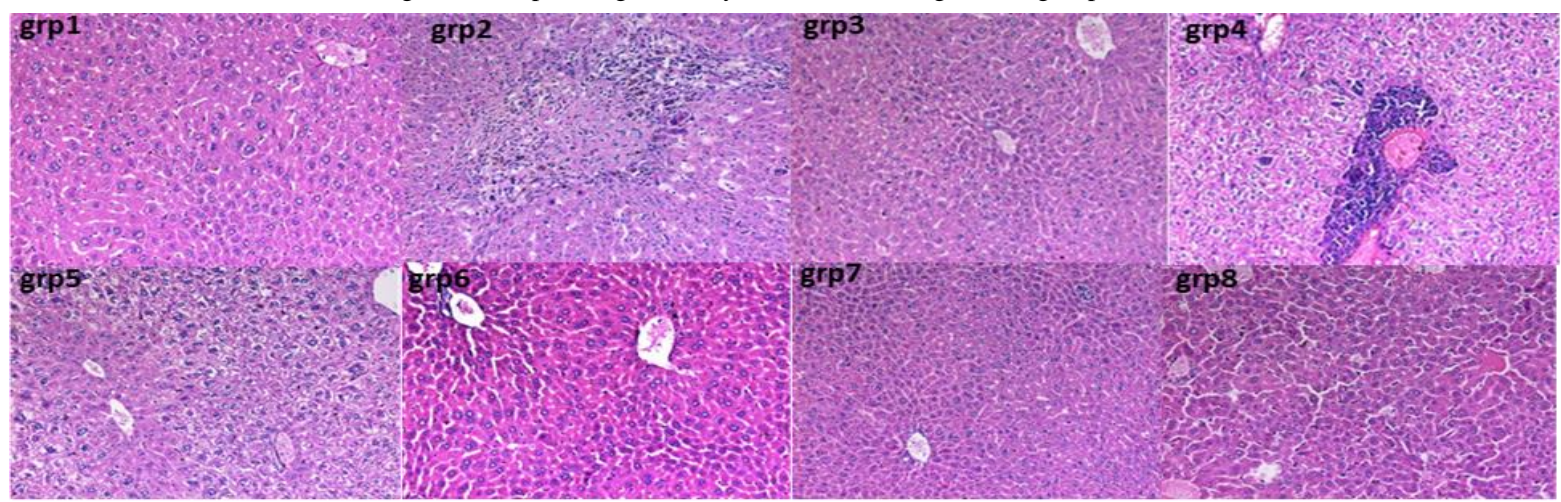

Fig. 15: Histopathological study for liver of mice groups (X40). 